\title{
EFFECTS OF AN ISOTONIC AND A COMBINATION ISOMETRIC-ISOTONIC EXERCISE PROGRAMME UPON PUSH-UP PERFORMANCE
}

\author{
J. W. BARKER, M.Sc.* \\ North Carolina State University, Raleigh, North Carolina
}

\begin{abstract}
The effects of a repetition push-up exercise programme and a repetition combination isometric-isotonic push-up exercise programme upon muscular endurance as measured by maximum repetition of push-ups were studied. Thirty-four male subjects enrolled in a wrestling activity class were equated into three groups on the basis of maximum repetition push-up performance. Group $1(N=12)$ performed maximum repetition push-ups; Group $2(N=11)$ did maximum repetition combination isometric-isotonic push-ups; and Group $3(N=11)$ served as the control group. Subjects in Groups 1 and 2 performed their exercises, after which all subjects participated in wrestling activities. All subjects were retested six weeks later after the two experimental groups had been subjected to twelve exercise periods. Both experimental groups showed statistically significant improvements in maximum repetition push-up performance. There was not a statistically significant difference between the mean increases of the two experimental groups. Within the limits of this study the results indicated that muscular endurance may be improved at nearly the same rate by both repetition push-up exercises (isotonic) and repetition combination isometric-isotonic push-up exercises.
\end{abstract}

\section{Review of Literature}

Research concerning the effects of combination isometric-isotonic training on various aspects of physical fitness is limited in quantity. Training with equipment designed to utilize both isometric and isotonic contractions $^{1}$ has shown improvement in baseball velocity (13), body conditioning (11), strength of professional football players $(7,16)$, pull-ups and dips (1), shot-put performance (3), and certain physical fitness components (2). Henriksen (8) reported that a group training with both isometric and isotonic deadlifts recorded significant improvement in two static positions of the deadlift, but overall was not a significantly better training programme than isometric or isotonic programmes.
It has been reported in several studies $(6,9,14,17$, 18) that muscular endurance is improved at approximately the same rate by both isometric and isotonic exercise programmes. "Push-ups" (or "press-ups") have been recognised as a suitable measure of muscular endurance $(4,5,10,15)$. According to Cureton's validity and factor analysis of 28 muscular endurance items (5), the floor push-up ranked third as a predictor of all-round muscular endurance, with the mile run and chinning ranked first and second, respectively. Push-up performance has been improved by general endurance work (10), isometrics, weight-training, and regular physical education activities (15), but no research has been reported which shows the effects of combination isometric-isotonic exercises upon push-up performance.

\section{Purpose}

This study investigated the effects of a maximum repetition isotonic push-up exercise programme and a maximum repetition combination isometric-isotonic push-up exercise programme on muscular endurance as measured by push-up performance.

\section{Methodology}

\section{SUBJECTS}

Subjects for this study were 34 male university students, 18 to 21 years of age, who were enrolled in a wrestling activity class in the required physical education service programme at Auburn University, Autumn term, 1967. All of these subjects had been approved for wrestling by the university physician. The subjects were equated into three groups: Group $1(\mathrm{~N}=12)$ performed maximum repetition push-ups; Group $2(\mathrm{~N}=11)$ performed maximum repetition combination isometric-isotonic push-ups; and Group $3(\mathrm{~N}=11)$, the control group, performed no special training. All 34 subjects participated in the wrestling class activities.

\section{TESTING PROCEDURES}

Maximum repetition push-ups were performed by all subjects before (T-1) and after (T-2) the experimental

${ }^{1}$ Sample commercial equipment includes: Exer-Genie Exerciser, from Exer-Genie Inc., P.O. Box 3237, Fullerton, Calif.; Telepander, from Margrace Corp., 250 West 57th St., N.Y., N.Y.; and Transversal Multi-Sporter, from Multi-Trainer, Box 1005, Graham, Texas.

*Based upon a thesis submitted in partial fulfillment of the requirements for the Master of Science degree at Auburn University, May 1968. 
period, with the same verbal instructions, as described by Clarke (4), being given each time. Testing conditions were nearly identical for both testing periods. Subjects started from the down push-up position and scored one point every time the subject's arms were completely straightened and the push-up properly executed. Only one-half point was scored if: (1) arms were bent at the top of the movement; (2) any part of the body other than the hands or toes touched the floor; (3) shoulders were pushed up first while the hips were stationary near the floor; or (4) hips were raised upward before the shoulders were pushed up. If any one position was held for two seconds, the test ended for that subject. Subjects worked in pairs, with one counting as the other executed the push-ups.

\section{TRAINING PROGRAMME}

All subjects met twice a week on the same days at the same hour for a period of six weeks. A brief warm-up period, consisting of general exercises, preceeded the experimental exercises. After the experimental exercises were completed, scores were recorded and the wrestling activities started for all subjects. All subjects were asked not to take part in any isometric or isotonic exercise programmes outside of class.

Group 1 performed maximum repetition isotonic push-ups identically to the T-1 test.

Group 2 executed maximum repetition combination isometric-isotonic push-ups every training session. A partner stood straddle of the prone subject, placed his hands over the medial area of the prone subject's scapulae, and applied sufficient resistance downward to prohibit upward motion in the attempt to push-up (Figure 1). The bottom subject was instructed to exert

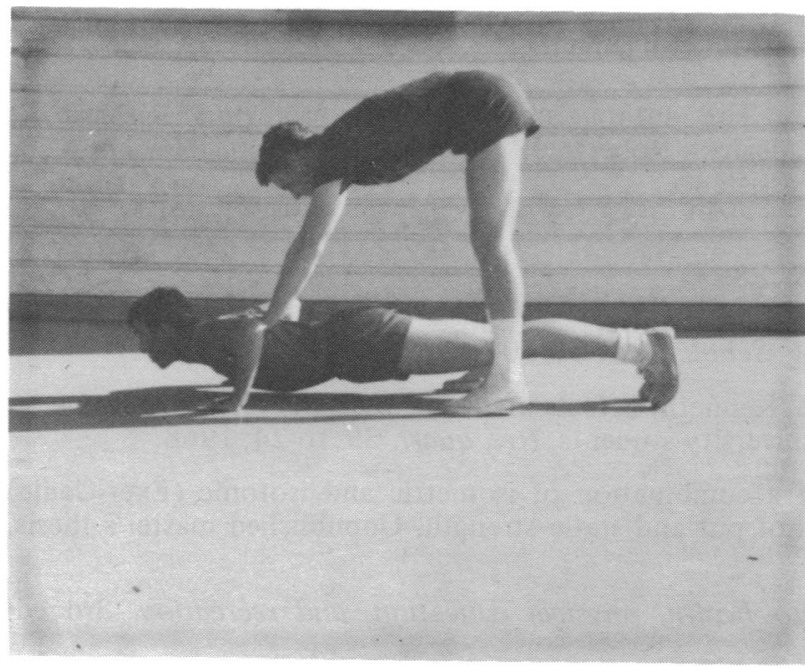

Figure 1. Isometric down-position of the combination isometric-isotonic push-up. near-maximum effort for approximately six seconds, thus constituting the isometric portion of the exercise. After the 6-second isometric contraction, resistance was removed and one isotonic push-up was performed (Figure 2). Upon returning to the down push-up position, another isometric position was held, and the procedure was repeated until the prone subject could complete no more push-ups.

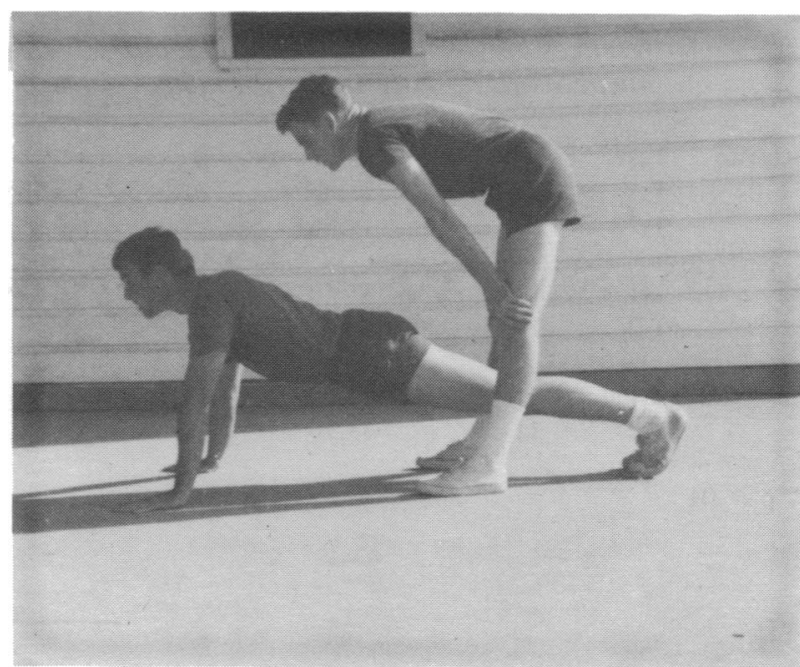

Figure 2. Isotonic up-position of the combination isometric-isotonic push-up.

\section{Summary of Results}

One-way analysis of variance was used to determine significant differences (.10 level) among the groups prior to training. A non-significant F-ratio $(0.122)$ was obtained.

Two-way analysis of variance was used to determine significant differences (.10 level) among the groups at T-2.

Table 1

Analysis of Variance: T-2 Push-up Scores for Groups 1, 2, and 3

$\begin{array}{lrrrr}\text { Source of Variance } & \text { Sums of Squares } & d f & \begin{array}{l}\text { Mean } \\ \text { Squares }\end{array} & F \\ \text { Between Groups } & 667.85 & 2 & 333.925 & 3.064 * \\ \text { Within Groups } & 3377.71 & 31 & 108.958 & \\ \text { Total } & 4045.56 & 33 & & \\ { }^{* p} \geqslant .10 & & & & \end{array}$

The t-test for correlated (nonindependent) means was used to analyse the mean pre- and post-training scores within each group. Both the maximum repetition 
push-up (Group 1) and the combination isometric-isotonic push-up (Group 2) groups showed significant improvement in push-up performance following a six-week training programme. The control group (Group 3) did not show a statistically significant improvement in push-up performance (Table 2).

\section{Table II}

\section{Differences between Pre- and Post-Training Mean Scores in Push-up Performance}

\begin{tabular}{|c|c|c|c|c|c|c|c|c|c|c|}
\hline \multirow{3}{*}{$\begin{array}{l}\text { Group } \\
1\end{array}$} & \multirow{4}{*}{$\begin{array}{l}\text { Test } \\
\text { T-1 } \\
\text { T-2 }\end{array}$} & \multirow{3}{*}{$\begin{array}{l}N \\
12 \\
12\end{array}$} & \multirow{3}{*}{$\begin{array}{l}\text { Mean } \\
33.33 \\
44.66\end{array}$} & \multirow{3}{*}{$\begin{array}{l}D \\
11,333\end{array}$} & \multirow{2}{*}{$\begin{array}{l}\mathrm{t} \\
5.156^{*}\end{array}$} & \multicolumn{5}{|c|}{ of Groups in Push-up Performance } \\
\hline & & & & & & \multirow[b]{2}{*}{ Groups } & & & \multirow{3}{*}{$\begin{array}{l}\text { D } \\
3.924\end{array}$} & \multirow{3}{*}{$\begin{array}{l}\mathrm{t} \\
1.471\end{array}$} \\
\hline & & & & & & & $\mathbf{N}$ & Mean & & \\
\hline & & & & & & 1 & 12 & 11.333 & & \\
\hline \multirow[t]{3}{*}{2} & T-1 & 11 & 31.40 & 7.409 & $5.184 *$ & 2 & 11 & 7.409 & & \\
\hline & $\mathrm{T}-2$ & 11 & 38.81 & & & & & & & \\
\hline & & & & & & 1 & 12 & 11.333 & 9.606 & $3.684^{*}$ \\
\hline \multirow[t]{3}{*}{3} & T-1 & 11 & 32.18 & 1.727 & 1.325 & 3 & 11 & 1.727 & & \\
\hline & $\mathrm{T}-2$ & 11 & 33.90 & & & & & & & \\
\hline & & & & & & 2 & 11 & 7.409 & 5.682 & $2.951^{*}$ \\
\hline \multirow[t]{2}{*}{${ }^{*} p \geqslant .01$} & & & & & & 3 & 11 & 1.727 & & \\
\hline & & & & & & ${ }^{*} \mathrm{p} \geqslant .0$ & & & & \\
\hline
\end{tabular}

\section{Summary}

The results reported in this study were in agreement with similar studies $(3,8)$ that have shown an increase in certain fitness components both by combination isometric-isotonic training and by isotonic training.

There was not a significant difference between the maximum repetition isotonic push-up group and the combination isometric-isotonic push-up group following six weeks of training.

\section{Conclusions}

The mean increases for Groups 1 and 2 were
To analyse the difference between mean increases among the three groups, the t-test for independent means was used. There was not a statistically significant different between the mean increases of the two experimental groups. Each of the experimental groups, however, showed a statistically significant improvement in push-up performance (.01 level) at T-2 over the control group (Table 3).

Table III

\section{Differences between Mean Increases} of Groups in Push-up Performance

al

considered to have resulted from (1) functional local muscular endurance improvement, and (2) acquisition of skill in push-up performance.

There is no significant difference in the effect of maximum isotonic and combination isometric-isotonic push-up training on ability to perform maximum repetition push-ups.

\section{Acknowledgements}

The author is indebted to Professors Richard $\mathrm{K}$. Means, Robert J. Francis and John Puckett for assistance.

\section{REFERENCES}

1. ALEXANDER, Bill. A new style of basketball conditioning. Schol coach 37:30 \& 34, 1967.

2. ALEXANDER, John F., MARTIN, Stephen L.; and METZ, Kenneth. Effects of a four-week training programme on certain physical fitness components of conditioned male university students. Res. quart. 39:16-24, 1968.

3. ANTONE, Gene. A comparative study of the effects of a combination of isometric and isotonic (Exer-Genie) training with isotonic training (weight-training) on the shot put and static strength. Unpublished master's thesis, San Jose State College, 1965.

4. CLARKE, H. Harrison. Application of measurement to health, physical education, and recreation. 3rd ed. Englewood Cliffs, N. J.: Prentice-Hall, Inc., 1959.

5. CURETON, Thomas, K., et.al. Endurance for young men. Washington: National Research Council, Society for Research in Child Development, 1945. 
6. DENNISON, I. D.; HOWELL, Maxwell L.; and MORFORD, W. R. Effect of isometric and isotonic exercise programmes upon muscular endurance. Res. quart. 32:348-52, 1961.

7. FRIEDMAN, Arnie. Wizard muscle maker for Conejo's gridders. News-Chronicle, Thousand Oaks, California, August 7, 1966, p. 4-5.

8. HENRIKSEN, Guy R. The effects of isotonic, isometric and combined isotonic-isometric resistance programmes on back strength. Unpublished master's thesis, University of Illinois, 1965.

9. HOWELL, Maxwell L.; KIMOTO, Ray; and MORFORD, W. R. Effect of isometric and isotonic exercise programmes upon muscular endurance. Res. quart. 33:536-40, 1962.

10. KNOWLTON, Ronald. A muscular endurance study of preadolescent boys. Unpublished master's thesis, University of Illinois, 1957.

11. LEWIS, Fred. A dynamic approach to body conditioning. Ath. J. 47:26-27, 1966.

12. LINN, Charles. A study of the desirability of the use of isometric contraction exercises in strengthening the shoulder girth muscles of eighth-grade boys participating in physical education. Unpublished master's thesis, University of Wyoming, 1965.

13. LOGAN, Gene A., et.al. Effects of resistance through a throwing range-of-motion on the velocity of a baseball. Percept. mot. skills 23:55-58, 1966.

14. MEADOWS, Paul E. The effects of isometric and isotonic muscle contraction training on speed, force and strength. Unpublished doctoral dissertation, University of Illinois, 1958.

15. RALLIS, Socrates. A comparison of three training programmes and their effects on five physical fitness components. Unpublished master's thesis, Wayne State University, 1965.

16. ROY, Alvin. The strength programme of the San Diego Chargers. Strgth \& Hlth. 33:14-17, 62, 63, 1965.

17. SCHLEEDE, Joan. Comparative effects of isometric and isotonic training methods on selected physical performance tests with women physical education majors. Unpublished doctoral dissertation, New York University, 1964.

18. THORNTON, Donald. The effects of isotonic and isometric strength training on pull-up achievement. Unpublished master's thesis, Michigan State University, 1965.

\section{MEETINGS OF OTHER ORGANISATIONS}

\section{BRITISH SOCIETY OF SPORTS PSYCHOLOGY}

Chairman: Dr. H. T. A. Whiting, M.A., Department of Physical Education, University of Leeds.

Treasurer: K. Hardman, M.A., M.Ed., Dept. of P.E., University of Liverpool, Tel. 061-643-5331

The British Society of Sports Psychology will be holding its Seventh Annual conference from September 7th to 9th, 1973 , at the University of Leeds.

For further details apply to the Hon Secretary, Miss Marilyn G. Jones, M.Ed., Bedford College of Physical Education, Lansdowne Road, Bedford. Tel. Bedford 51966/7/8. 